\title{
Alveolar macrophage functions during the transition phase to active immunity in calves $^{1}$
}

\author{
Heloisa G. Bertagnon, ${ }^{*, \dagger, 2}$ Camila F. Batista, ${ }^{\dagger}$ Kamila R. Santos, ${ }^{\dagger}$ Renata C. Gomes, ${ }^{\dagger}$ \\ Jessyca B. Bellinazzi, ${ }^{\dagger}$ and Alice Maria M. P. Della Libera ${ }^{\dagger}$
}

*Department of Veterinary Medicine, University of Centro Oeste of Parana (UNICENTRO), Guarapuava, PR 85040-080, Brazil; and Department of Internal Medicine, Faculty of Veterinary Medicine and Animal Science, University of Sao Paulo, Sao Paulo, SP 05508-270, Brazil

\begin{abstract}
The first 3 to 6 mo of the life of calves is the period during which active immunity is established. During this period, greater morbidity and mortality is caused by bronchopneumonia because of the immaturity of the pulmonary immune system or the exaggerated cytotoxic response at subsequent infection. The aim of this study was to examine the maturity of the immune system during this phase of activation of acquired immunity in calves. For this purpose, the functions of phagocytosis and the reactive oxygen species (ROS) of alveolar macrophages CD14+ were evaluated. Further, the classes of immunoglobulins and the cytokines implicated in lymphocyte response patterns Th1 and Th2 in 10 healthy Holstein calves were quantified. Samples were taken from calves every $15 \mathrm{~d}$, from the third to the sixth month of life. The alveolar macrophage CD14+ functions increased progressively until $150 \mathrm{~d}$ of age (phagocytosis, $P=0.02$, ROS, $P=0.05), \operatorname{IgG} 1$ and $\mathrm{IgG} 2$ isotype secretion
\end{abstract}

reached an equilibrium, and the cytokine profiles were compatible with the Th1 response. At 165 $\mathrm{d}$ of age, there was a decrease in cellular function (phagocytosis $P=0.02$, ROS $P=0.04$ ) and an increase in IgG1 titers $(P=0.005)$ and IL-10 mRNA expression $(P=0.09)$. At $180 \mathrm{~d}$ of life, we observed an IgG1 and IgG2 secretion balance, a decrease in IL-10 mRNA expression, and an increase in IL-12 mRNA $(P=0.04)$ and tumor necrosis factor (TNF)- $\alpha$ mRNA expressions $(P=0.0003)$ and alveolar macrophage oxidative metabolism were observed. These results indicate that the calves had an active immune response that was distinctive for the age group. The CD14+ response is more reactive at $150 \mathrm{~d}$. A regulatory and/or humoral response begins at $165 \mathrm{~d}$ of life as the equilibrium of Th1 and Th2 profiles is reached at $180 \mathrm{~d}$ of life. This may be clinically relevant for the development of specific therapies and prophylactic measures for bronchopneumonia in calves at 135 to $180 \mathrm{~d}$ of life.

Key words: cattle, cytokines, immunoglobulin, lungs, reactive oxygen species, Th1

(C) The Author (s) 2018. Published by Oxford University Press on behalf of the American Society of Animal Science. All rights reserved. For permissions, please e-mail: journals.permissions@oup.com.

J. Anim. Sci. 2018.96:3738-3747 doi: 10.1093/jas/sky261

\section{INTRODUCTION}

Although the susceptibility of calves to respiratory diseases is higher between the first and fifth months of life (Gonçalves et al., 2000),

${ }^{1}$ This research was suported by FAPESP -2011/17606-3; 2018/15787-0, 141127/2011 CNPQ and CAPES.

${ }^{2}$ Corresponding author: hbertagnon@hotmail.com

Received April 2, 2018.

Accepted June 28, 2018. studies typically focus only on the first 3 mo of life (Kalina et al., 2005; Cortese, 2009; Ackermann et al., 2010; Batista et al., 2012). There is a lack of information regarding the period from the third to the sixth month of life, a period during which the individual's immunity is established independent of maternal factors (Cortese, 2009). Experimentally induced infections show that bovine neonates assemble a less robust inflammatory response, and viral elimination is inefficient 
compared with that in animals of intermediate age (3 to 5 mo; Grell et al., 2005a, 2005b; Platt et al., 2009). This fact suggests that during this stage, the most prominent inflammatory response is related to an exaggerated immune response. This corroborates evidence from the literature that suggests a greater severity of bronchopneumonia (Grell et al., 2005a; Platt et al., 2009), and higher levels of mortality for that disease (Gorden and Plummer, 2010), occur between the third and fifth months of age. In addition, there is a possible imbalance in the Th1 and Th2 profiles (Mena et al., 2002; Ohtsuka et al., 2002; Grell et al., 2005b), which would be a determining factor in the exaggerated immune response (Meyer et al., 2008; Platt et al., 2009; Antonis et al., 2010). Maturation of the pulmonary immune system is not concluded until the third month of life and calves display high susceptibility to bronchopneumonia that extends until the fifth month of life (Gonçalves et al., 2000; Gorden and Plummer, 2010). The objectives of this study were therefore to assess the maturation of the cell and humoral bronchoalveolar immunity, and determine trends in the Th1 and Th2 profiles and the intensity of the cytotoxic response during the third to sixth months of life.

\section{MATERIALS AND METHODS}

Our project was approved by the Ethics Committee on the Use of Animals in the Faculty of Veterinary Medicine and Animal Science of the University of Sao Paulo_FMVZ USP (2224/2011).

\section{Animals and Sample Collection}

Ten male Holstein bulls were monitored during the third to sixth months of life. These animals came from properties near Sao Paulo, and all had received 2 liters of colostrum on the property. They were transported to the experimental sector of FMVZ-USP at $1 \mathrm{wk}$ of age, and were acclimated until they reached the proper age for the experiment. The total protein and $\gamma$-globulin of all the animals were $6 \pm 0.8 \mathrm{~g} / \mathrm{dL}$ and $1.3 \pm 0.5 \mathrm{~g} /$ $\mathrm{dL}$, respectively, at the first week of life. The calves received bottles of bovine milk (for a total dose of $10 \%$ of live weight, divided into two periods at $12-\mathrm{h}$ intervals), commercial ration, and hay. At $60 \mathrm{~d}$ of age, when they consumed more than $1 \mathrm{~kg}$ of commercial ration, they were weaned and only fed commercial ration, hay, and water ad libitum. During this time and until the time the animals left the experiment, the calves were allocated into groups of two or three animals per bay $(1 \times 2 \mathrm{~m})$ during the night, and during the day, into groups of five animals in a common cement enclosure $(5 \times 7 \mathrm{~m})$ with access to sunlight.

The animals were monitored to ensure their health during the study. The animals underwent clinical examinations daily, and their hemograms were evaluated weekly. No abnormalities were found in these animals upon clinical examination or in the hemograms, based on the standards of Bertagnon et al. (2011) and Gonçalves et al. (2000). As the criteria for healthy lungs were used in the study, only bulls with little or lack of bronchial secretion were observed by bronchoscopy, and more than $60 \%$ of the alveolar macrophages in bronchoalveolar cell was observed by cytology (Supplementary material 1).

The bronchoalveolar immune function of these animals was assessed at seven experimental time points for each calf, and each time point represented a distinct period of time. Five animals were studied from March to May (winter season), and the other five animals were studied from November to January (summer season). Two or three animals were randomly sampled per day in order to avoid daily variability in the assay and environmental effects that could confuse the age-related effects of interest. Samples were taken every $15 \mathrm{~d}$ for each calf. The first time point (T1) was at $90 \pm 2 \mathrm{~d}$ of life, the second (T2) at $105 \pm 2 \mathrm{~d}$, the third (T3) at $120 \pm 2 \mathrm{~d}$, the fourth (T4) at $135 \pm 2 \mathrm{~d}$, the fifth (T5) at $150 \pm 2 \mathrm{~d}$, the sixth (T6) at $165 \pm 2 \mathrm{~d}$, and the seventh (T7) at $180 \pm 2 \mathrm{~d}$.

Blood samples were collected by jugular venipuncture by a vacuum method, using tubes without any anticoagulant. The blood serum was separated by centrifugation $(1,500 \times g$ for $15 \mathrm{~min})$ and frozen $\left(-40{ }^{\circ} \mathrm{C}\right)$ until processing.

Bronchoalveolar lavage (BAL) was collected by endoscopy using a flexible video gastroscope (EG-250PE5, FujinonR, Fujifilm Corp., Tokyo, Japan). The video gastroscope was inserted nasopharyngeally using $60 \mathrm{~mL}$ of sterile saline solution injected through the working channel and aspirated with a vacuum cleaner, leading to the recovery of approximately $50 \mathrm{~mL}$ of BAL (Batista et al., 2012). The collected material was stored in conical tubes of $50 \mathrm{~mL}$ and immersed in ice until processing the samples, but not for more than $3 \mathrm{~h}$.

\section{Immunoglobulin Quantification}

After centrifugation of BAL samples $(1,000 \times g$ for $15 \mathrm{~min}$ at $4{ }^{\circ} \mathrm{C}$ ), we stored the supernatant in microtubes and froze them at $-20{ }^{\circ} \mathrm{C}$. The BAL 
and blood serum samples were used for quantification of the immunoglobulins (IgG1, IgG2, IgA, and $\mathrm{IgM}$ for $\mathrm{BAL}$ and $\mathrm{IgG} 1$ and $\mathrm{IgG} 2$ for blood serum) using a double-antibody sandwich ELISA specific for bovine immunoglobulin (Cat. D6883; $0.3 \mathrm{mM}$, Sigma Aldrich, St. Louis, MO, USA). The BAL concentrations of specific immunoglobulins were determined by comparison with a standard curve generated from previously known concentrations of bovine $\operatorname{IgA}, \operatorname{IgM}, \operatorname{IgG}, \operatorname{IgG} 1$, or $\operatorname{IgG} 2$. The samples dilutions were $1: 2$ to $\operatorname{IgM}, 1: 10$ to $\operatorname{IgG} 1$, $1: 10$ to $\operatorname{IgG} 2$, and $1: 200$ to $\operatorname{IgA}$, for BAL, and the manufacturer recommendations were followed for the dilutions of the blood serum.

\section{Flow Cytometry}

The cell pellet was washed with $1.2 \%$ phosphate buffered saline solution (PBS) and centrifuged $\left(1,000 \times g\right.$ for $15 \mathrm{~min}$ at $\left.4{ }^{\circ} \mathrm{C}\right)$. The samples used for flow cytometry assay were suspended in the cell culture medium (RPMI 1640 enriched with $10 \%$ bovine fetal serum at $2 \times 10^{6}$ viable cells $\mathrm{mL}^{-1}$ ) based on trypan blue exclusion (Koess and Hamann, 2008). All the samples showed a viability greater than $90 \%$.

Assays were carried out on cell populations quantified as a proportion of total bronchoalveolar cells and of a total CD14+ bronchoalveolar cells. In these two populations, we identified the indirect production of intracellular reactive oxygen species (ROS) and phagocytosis using the flow cytometry technique (Kampen et al., 2004). Briefly, $2 \times 10^{5}$ of BAL cells were incubated in a PBS solution at $37^{\circ} \mathrm{C}$ for 30 min with $100 \mu \mathrm{L}$ of Escherichia coli (O98:H28) combined with propidium iodide-EcPI (at the concentration of $25 \times 10^{6}$ bacteria $\mathrm{mL}^{-1}$ ), and accompanied or not by $200 \mu \mathrm{L}$ of dichloro-dihydro-fluorescein diacetate (DCFH-DA, Cat. No. MM61A, VMRD, Pullman, WA, USA). Subsequently, we marked the surface molecules CD14 (anti-bovine CD14 antibody, Cat. No. A10530, Life Technologies, San Diego, CA, USA) and IgG1-APC (Cat. No. A10530, Life Technologies, San Diego, CA, USA) for $30 \mathrm{~min}$ each. The samples were analyzed in a flow cytometer (FACSCalibur flow cytometer, Becton Dickinson Immunocytometry Systems, San Diego, CA, USA), connected to a computer program (BD CellQuest Pro software version 5.1, BD Immunocytometry Systems, San Diego, CA, USA 120). In total, 20,000 events were recorded for each tube and analyzed using specialized software (FlowJo version 10.07, Treestar, SA) to measure the arbitrary values of geometric mean fluorescence intensity (GMFI) and the percentage of CD14 molecule expression from the total amount of bronchoalveolar cells. The functions of phagocytosis and ROS production were measured from the bronchoalveolar cells and from the CD14+ bronchoalveolar cells. The negative controls were the unlabeled cells and the positive controls were cells labeled with each fluorochrome (Supplementary material 2).

\section{Real-Time PCR Analysis}

In samples used for the quantification of cytokines, the cell pellet was dissolved in $500 \mu \mathrm{L}$ of Trizol reagent and frozen at $-80{ }^{\circ} \mathrm{C}$ until the time when mRNA analysis was performed. A quantitative real-time PCR approach was used for cytokine mRNA analysis. RNA was harvested using a kit (PureLink RNA Mini, Total RNA Isolation System, Invitrogen Corp., SP, Brazil) and the samples were digested with DNAse (DNASE I Invitrogen Corp., SP, Brazil) using a commercial enzyme, according to the manufacturer's instructions. The purity and concentration of the RNA were evaluated using a spectrophotometer and all samples had a 260/280 ratio of 1.7 to 2.0. Complementary DNA was synthesized in the presence of random primers and reverse transcriptase (Sensiscript RT Kit, Qiagen, SP, Brazil) according to the manufacturer's instructions.

Quantitative PCR was performed using gene expression assays (Kabara et al., 2014). All the primers were predesigned commercially (tumor necrosis factor, TNF- $\alpha$-Bt 03259156-m1, IL-12-Bt 03213923-m1, IL-10-Bt 03212727-m1; Applied Biosystems, Carlsbad, CA, USA). Samples were assayed in duplicate with $20 \mathrm{ng}$ of DNA per reaction $(2.5 \mu \mathrm{L})$ along with $10 \mu \mathrm{L}$ of Master Mix (TaqMan Fast Universal Master Mix PCR, Invitrogen Corp., SP, Brazil) and $0.5 \mu \mathrm{L}$ of appropriate Gene Expression Assay on the Real-Time PCR System (7500 Real-Time PCR System, Applied Biosystems, Carlsbad, CA, USA). PCR amplification was performed in capped 96-well optical plates. The negative controls were ultrapure DEPC-treated water and the positive controls for signal detection were the cells of an adult animal. The real-time PCR was programmed for an initial step of $2 \mathrm{~min}$ at $50{ }^{\circ} \mathrm{C}$ and $10 \mathrm{~min}$ at $95^{\circ} \mathrm{C}$, followed by 40 cycles of $15 \mathrm{~s}$ at $95^{\circ} \mathrm{C}$ and $1 \mathrm{~min}$ at $60^{\circ} \mathrm{C}$.

Reaction efficiency (E) was calculated from standard curves for each gene, using the formula $E=(e[-1 /$ slope $] 150-1)$. The reaction efficiency for 
different cytokines was $80 \%$ for IL-12, IL-10, and $\beta$-actin; $110 \%$ for TNF- $\alpha$; and $82 \%$ for GAPDH.

The relative quantification of TNF- $\alpha$, IL-12, and IL-10 was calculated using software $(7500$ Real-Time PCR System, Applied Biosystems, Carlsbad, CA, USA). Data were calculated based on relative expression ratios of single samples with an efficiency correction (Pfaffl et al., 2002), using $\beta$-actin and GAPDH ( $\beta$-actin-Bt-03279174-g1, GAPDH-Bt 032109113-g1, Applied Biosystems, Carlsbad, CA, USA) as the control reference gene (Pfaffl et al., 2002; Holmgren et al., 2014; Kabara et al., 2014).

\section{Statistical Analysis}

Analysis of the data with the Shapiro-Wilk test revealed that the cytokines data were not normally distributed; thus, nonparametric analyses were used for these data. The Freidman test was used to analyze the variance, and the Dunn multiple comparison test was used for nonparametric data. The flow cytometry and the immunoglobulin quantification data were normally distributed. A parametric repeated-measures test was used to analyze the variance, and Tukey's multiple comparison test was also conducted. A commercial statistical software program (SAS, version 9.3, SAS Institute Inc., Cary, NC) was used for analyses. Differences were considered significant at $P \leq 0.05$, and a tendency toward significance was defined as $0.05<P<0.10$.

\section{RESULTS}

CD14 molecule expression showed an increase in bronchoalveolar cells at $120 \mathrm{~d}$ of life (T3), higher than T1 $(P=0.04)$, and later, a decrease until $165 \mathrm{~d}$ (T6); expression was higher at T3 than at T5 $(P=0.04)$. Similar dynamics was observed in relation to the percentage of CD14+ cells phagocytosing E. coli. Activity also increased until $120 \mathrm{~d}$ of life (T3) and was higher than that at T1 $(P=0.009)$, with a subsequent reduction until $165 \mathrm{~d}$ of life (T6), at T3 was higher than at T5 and T6 $(P=0.01$; Fig. 1). Although there was a reduction in the percentage of phagocytosis of CD14+ cells, these cells internalized a greater number of bacterial particles, as evidenced by the high rates of GMFI at T5 and T6 in comparison to T3, T4, and T7 $(P=0.02)$, demonstrating higher activity of these cells (Fig. 2). Similar dynamics was observed in relation to the percentage and GMFI of bronchoalveolar cells phagocytosing E. coli although these differences were not significant (Figs. 1 and 2).

In oxidative metabolism, the percentage of ROS CD14+ cells increased progressively until $150 \mathrm{~d}$ of life (T5 higher than T1 $P=0.05$ ) followed by a decrease of the percentage of ROS CD14+ cells until T7 (T5 higher than T7 $P=0.04$; Fig. 1). No influence of age was observed on the MFI (Fig. 2). Similar dynamics were observed in relation to the percentage and GMFI of ROS bronchoalveolar cells, but the differences were not significant (Figs. 1 and 2).

IgA was the predominant class of immunoglobulin in BAL during the third to sixth month of life in calves, and the total levels of $\operatorname{IgA}$ and $\operatorname{IgM}$ were not influenced by age. The levels of $\mathrm{IgG1}$ and IgG2 showed equilibrium until $150 \mathrm{~d}$ of life (T4), followed by an increase in IgG1 (T6 higher than T1, T2, and T3, $P=0.005$ ) and a decrease in $\mathrm{IgG} 2$ that was not significantly different until $165 \mathrm{~d}$. The proportion $\mathrm{IgG} 1 / \mathrm{IgG} 2$ at $\mathrm{T} 6$ tended to be greater than at the earlier time points (T6 higher than T2, T3, and T4, $P=0.09$, data not showed). Later, there was an equilibrium between the two variables (Fig. 3). The serum blood IgG isotopes maintained a higher level of $\mathrm{IgG} 1$ relative to $\mathrm{IgG} 2$ at all times.

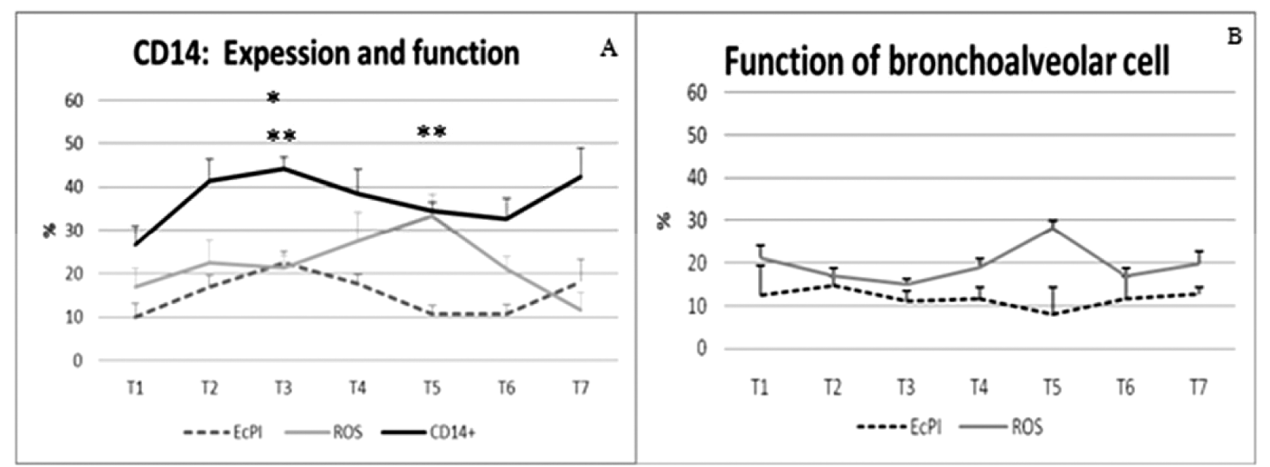

Figure 1. Flow cytometry of BAL cells measured by percentage of cells. (A) Detection of CD14+ cells and their functions from healthy calves. (B) Functions of bronchoalveolar cells from healthy calves. Means \pm SEM from 10 calves during the 3 to 6 mo of life. CD14+ were gate in total bronchoalveolar cells. EcPI, phagocytosis of E. coli by CD14+ cells; ROS, intracellular ROS production by CD14+ cells. *Statistical difference for CD14+ (T1 to T3 and T3 to T5, $P=0.04$ ) and for EcPI CD14+ (T1 to T3, $P=0.009$, and T3 to T5, T6, $P=0.01$ ). **Statistical difference for ROS (T5 to T1, $P=0.05$ and 5 to $\mathrm{T} 7, P=0.04$ ). 
In Figs. 4-6 we show the levels of the IL-10, IL-12, and TNF- $\alpha$ mRNA cytokines. The values are calculated based on the ratio of the threshold cycle $(\mathrm{Ct})$ of each target gene and the reference genes $\beta$-actin and GAPDH, corrected by the efficiency of the reaction. When the calves reached $150 \mathrm{~d}$ of life, we found a higher expression of IL-12 (T5 was higher than T6, $P=0.04$ ) and TNF- $\alpha$
(T5 was higher than all other time points, $P=0.003$ ). When the calves reached $165 \mathrm{~d}$ of life, we found a higher expression of IL-10 (T6 was higher than T5, $P=0.09)$.

\section{DISCUSSION}

This study aimed to investigate the influence of age on immune system maturity in calves between
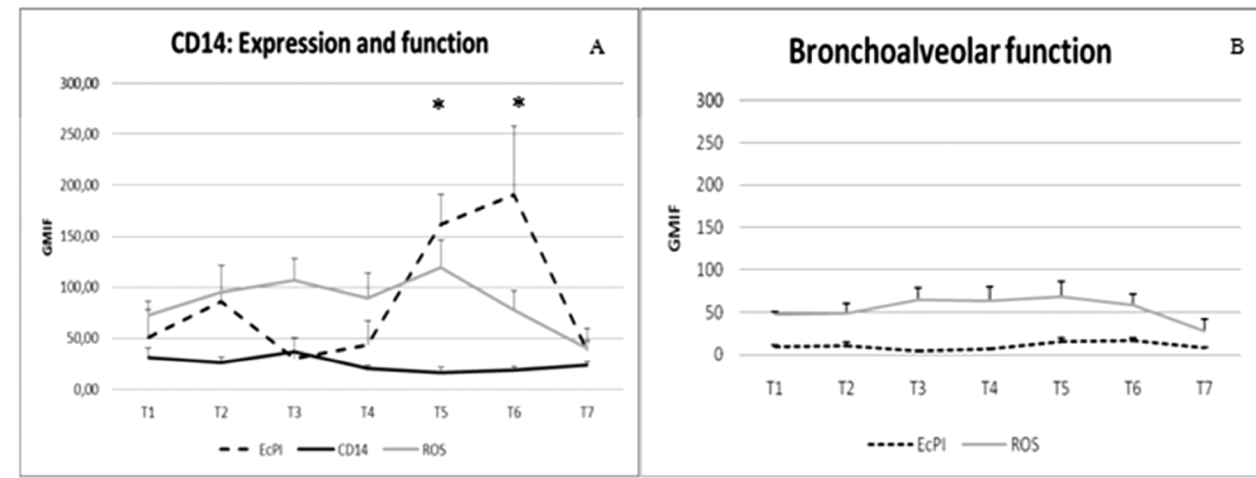

Figure 2. Flow cytometry of BAL cells measured by arbitrary values of GMFI. (A) Detection of CD14+ cells and their functions from healthy calves. (B) Functions of bronchoalveolar cells from healthy calves. Means \pm SEM expressed as arbitrary values from 10 calves during the 3 to 6 mo of life. EcPI, phagocytosis of E. coli by CD14+ cells; ROS, intracellular ROS production by CD14+ cells. *Statistical difference for EcPI (T5 and T6 to $\mathrm{T} 3$ and $\mathrm{T} 4, P=0.02)$.

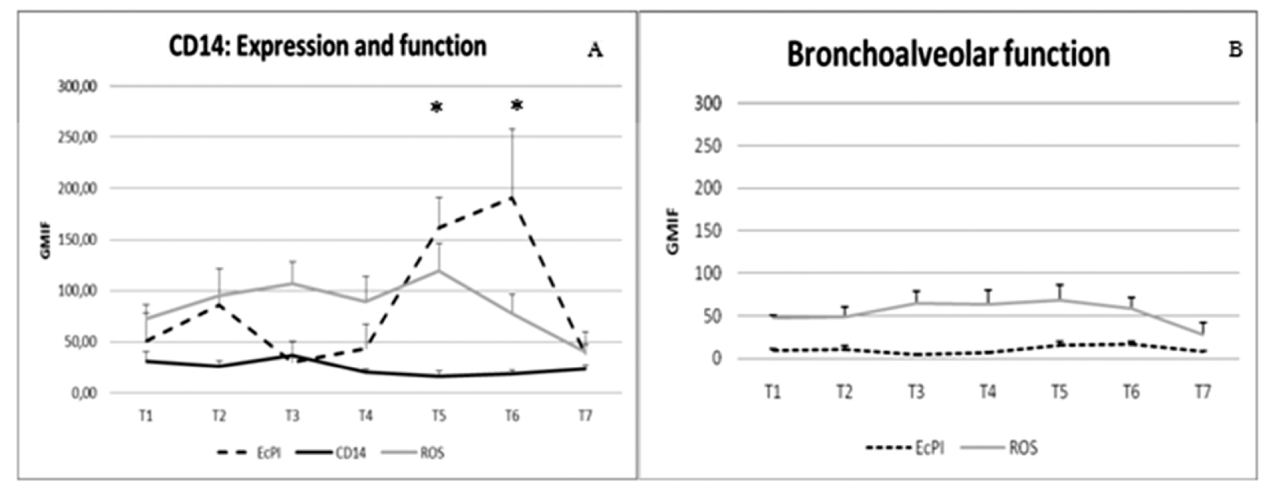

Figure 3. Immunoglobulin from healthy calves. (A) BAL sample; (B) blood serum. Means \pm SEM from 10 calves during the 3 to 6 mo of life. *Statistical difference for IgG1 BAL (T6 to T1, T2, and T3, $P=0.005$ ).

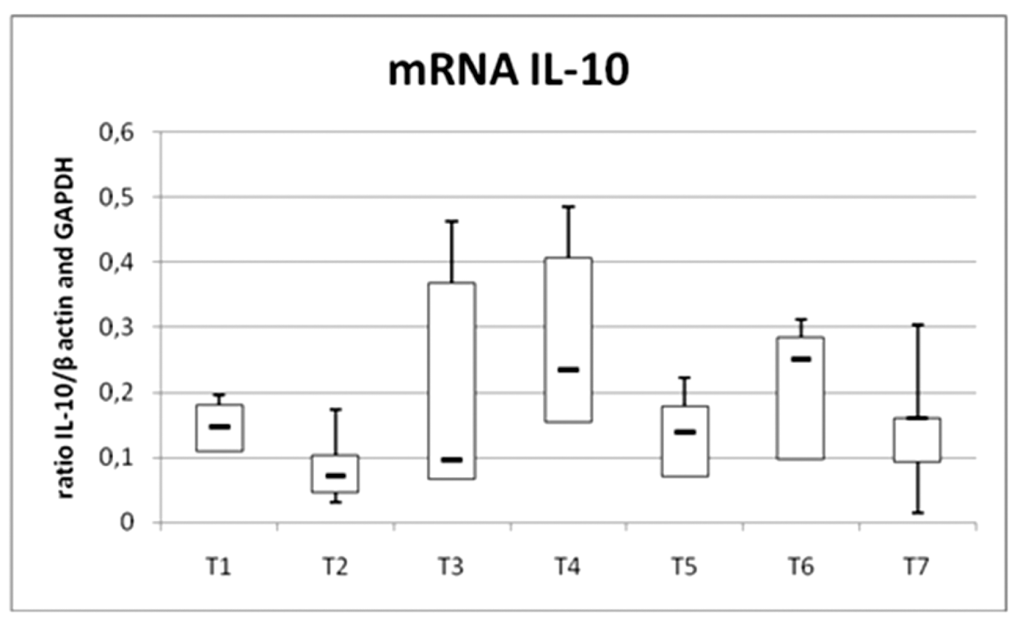

Figure 4. mRNA IL-10 expression by bronchoalveolar cells from healthy calves. Each box represents median with high values from 10 calves during the 3 to 6 mo of life. 


\section{m RNA IL-12}

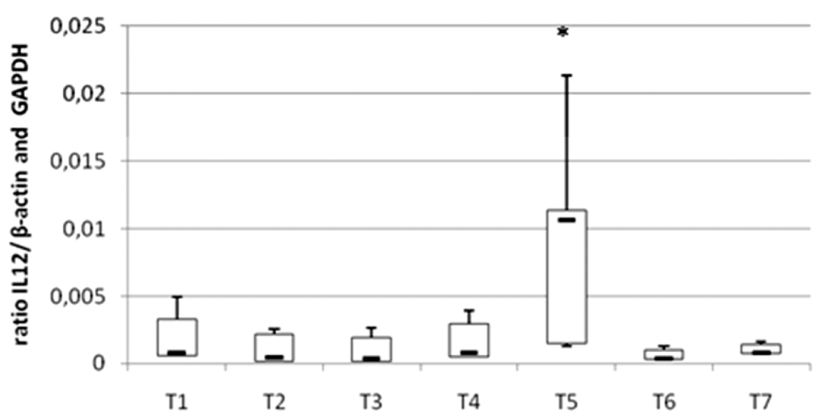

Figure 5. mRNA IL-12 expression by bronchoalveolar cells from healthy calves. Each box represent median with high values from 10 calves during the 3 to 6 mo of life. *Statistical difference M5 to M6, $P=0.04$.

\section{m RNA TNF- $\alpha$}

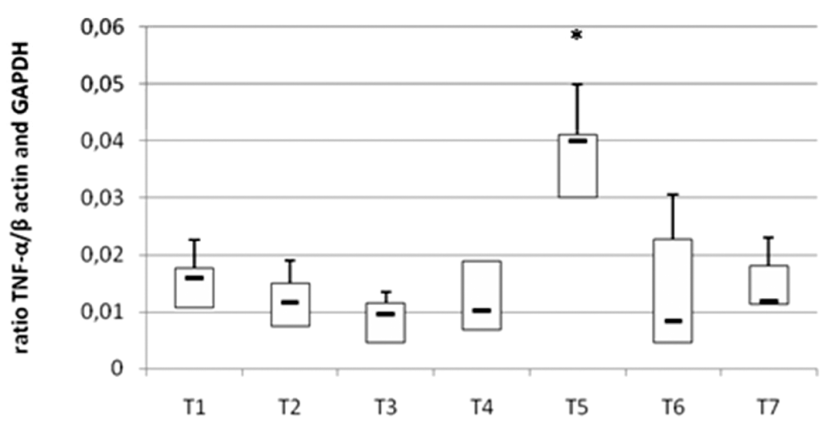

Figure 6. mRNA TNF- $\alpha$ expression by bronchoalveolar cells from healthy calves. Each box represents median with high values from 10 calves during the 3 to 6 mo of life. *Statistical difference between M5 and other moments, $P=0.003$.

the ages of 3 to 6 mo. To avoid confounding variables that could interfere with immune response, the calves were acclimated from birth and maintained under the same management system (Kampen et al., 2006), and specific inclusion criteria were adopted to ensure the health of animals, thereby minimizing factors other than age that might influence the results. To avoid possible seasonal effects on the pulmonary immune function, five animals were studied from March to May (winter), and another five animals were studied from November to January (summer). No significant differences were observed in the immune parameters of these two cohort studies (Supplementary material 3).

It has been reported that lavage procedures lead to an influx of neutrophils in the lungs as well as changes in lung surfactant for up to $3 \mathrm{wk}$ after BAL (Reinhold et al., 2000). We believe that the repetition of BAL caused little or no bronchoalveolar inflammation, because the animals maintained the percentage of neutrophils below $30 \%$ and the percentage of alveolar macrophages above $60 \%$ in bronchoalveolar cytology, and few or no bronchial secretions were observed by bronchoscopy at any point (Supplementary material 2).

Bronchoalveolar cells mainly comprise alveolar macrophages, neutrophils, lymphocytes, and epithelial cells (Ackermann et al., 2010). In the dispersion cytogram, it was not possible to separate these different populations; therefore, we chose to select the function of the alveolar macrophages as identified by the CD14 membrane receptor. The mean percentage of bronchoalveolar cells expressing the CD14 molecule was between 30 and $40 \%$, similar to the findings by previous studies on healthy cattle (Soethout et al., 2004; Batista et al., 2012). Because CD14 is a surface molecule expressed mostly by cells of the monocytic-macrophage lineage (Machugh et al., 2012), the large percentage of these cells that was observed was expected, because alveolar macrophages are the predominant cell type in the lungs in healthy cattle, accounting for 60 to $80 \%$ of the cytological count (Ackermann et al., 2010).

This finding can be attributed to a weak correlation between the techniques used for bronchoalveolar cytology and flow cytometry in identifying alveolar macrophages (Hodge et al., 2004).

The bronchoalveolar cells analyzed showed phagocytosis activity and ROS production lower than the CD14+ bronchoalveolar cells. The bronchoalveolar cells demonstrate similar dynamics to the CD14+ cells, but there were no statistically significant differences among time points $(P=0.1$ for $E$ coli $\%, P=0.24$ for $E$. coli GMFI, $P=0.31$ for $\mathrm{ROS} \%, P=0.39$ for ROS GMFI). This may be because this cell population is related to other cells (epithelial and large lymphocytes) or other sub-populations of macrophages that perform different functions in addition to phagocytosis and hence do not express the CD14 molecule, as suggested by Batista et al. (2012).

The increase of CD14 molecule expression possibly indicates the immaturity of the antigen-presenting cells until $120 \mathrm{~d}$ of life (T3), which would require a larger number of such cells to perform the same function than in a more mature cell (Reber et al., 2008).

Similar dynamics were observed in relation to the percentage of CD14+ cells phagocytosing E. coli. Based on these results, it appears that at $\mathrm{T} 1$ and $\mathrm{T} 2$ the cells were still immature with low capacity for phagocytosis. At T3, there was an increase in CD14+ cells, which began to increase their phagocytosis capacity but did not increase the production of ROS, confirming the hypothesis that because they are immature, they must be present in 
greater numbers to maintain a healthy respiratory tract (Ackermann et al., 2010).

At T5 (150 d of life), these CD14 + 234 cells were at the maximum efficiency. Although they were outnumbered, they were able to phagocytose $E$. coli and produce ROS in higher quantities than they could at the earlier time points and at T7 (180 $\mathrm{d}$ of life). This allows us to present two hypotheses. First, the bronchoalveolar cells reach maturity between $\mathrm{T} 4$ and $\mathrm{T} 5$, and they are mature, on average, when the calves reach an age of $150 \mathrm{~d}$ (T5); when calves reach an age of $180 \mathrm{~d}$, cellular activity in the bronchoalveolar cells decreases. During the growth of calves, common stress factors arising from management practices promote a reduction in immunity (Cortese, 2009; Bertagnon et al., 2011). However, because the study animals were subjected to the same management conditions and different seasonal conditions throughout the trial period, it was not possible to identify the causative factor for immune impairment.

For the second hypothesis, it can be inferred that to keep a healthy respiratory tract, there is an increased reactive inflammatory response at T5 characterized by excessive production of ROS; this can be considered an exacerbated cell immune response, which was under control by T7. An explanation for this can be obtained in the findings of Grell et al. (2005a, 2005b) and Platt et al. (2009), who showed that, when inoculated with pulmonary pathogens, symptoms were more pronounced, and the pulmonary damage was more intense, in calves between 3 and 5 mo of age, compared with older animals between 8 and 9 mo of age.

The immunoglobulins are produced and secreted in the respiratory tract and serve the function of neutralizing viruses, enzymes, and toxins, and of opsonizing pathogens (Kidd, 2003). As reported by Kalina et al. (2005) and Prado et al. (2006), IgA is the predominant immunoglobulin class during the first 6 mo of life in calves. We found, however, that the total levels of $\operatorname{IgA}$ and $\operatorname{IgM}$ were not influenced by age, contrary to the findings of Chase et al. (2008), who stated that the maximum residue level of immunoglobulins was achieved at 4 mo of age.

As previously reported (Kalina et al., 2005; Prado et al., 2006), the levels of IgG1 and $\mathrm{IgG} 2$ exhibit reversals according to the age of calves. As the IgG1 isotype is associated with the Th2 type response assisting in particle agglutination of antigens, and the $\mathrm{IgG} 2$ isotype is compatible with standard Th1 responses assisting in neutrophilic function (Kidd, 2003), it appears that until $150 \mathrm{~d}$ of life (T5), there was a balance in Th1 and Th2 profiles. A predominance of Th2 response occurred at T6 (165 d of life), and the equilibrium returned at T7. Similar results were obtained by Kalina et al. (2005) who compared profiles of immune responses in calves challenged with bovine respiratory syncytial virus (BRSV) at 3 to 4 mo of age and at 5 to 6 mo of age.

The blood $\mathrm{IgG}$ isotopes did not differ from those found in the bronchoalveolar region, maintaining a predominance of $\mathrm{IgG} 1$ in relation to $\mathrm{IgG} 2$ in serum at all times. In the bronchoalveolar region, there was a balance between the two isotopes up to T4, with a predominance of IgG1 between T5 and $\mathrm{T} 6$ and a later return to equilibrium between the two isotopes in T7. These facts reflect endogenous antibody production and not transport of blood $\mathrm{IgG}$ isotopes into the bronchoalveolar spaces.

The Th1/Th2 profile paradigm has been studied in bovine animals to assess the effectiveness of vaccines (Mena et al., 2002; Antonis et al., 2010) and the pathogenicity of parasitic infections (Ingale et al., 2008; Holmgren et al., 2014), but not under standardized conditions. It was determined that cytokines related to the Th1 pattern (IFN- $\gamma$, IL-2, IL-12, and TNF- $\alpha$ ) induce a predominantly cellular response, a cytotoxic effect, by activating natural killer (NK) cells. In addition, the cytokines increase neutrophilic chemotaxis, stimulate the production of IgG2 by B lymphocytes, and simultaneously regulate Th2 and regulatory lymphocytes, inhibiting the production of IL-4 and IL-10 (Kidd, 2003; Tizard, 2014).

Conversely, the Th2 cytokines profile, IL-4, IL-5, IL-6, IL-10, and IL-13, mainly induce production of IgE by lymphocytes, with proliferation and eosinophilic chemotaxis, featuring a predominantly allergic response that is common in humans and mice (Kidd, 2003). In cattle, it is not characterized as allergic and appears to be connected to the stimulation of $\mathrm{IgGl}$ secretion, inhibition of macrophage functions, and secretion of IL-12 and IFN- $\gamma$, thus inhibiting the Th1 response (Mena et al., 2002; Kidd, 2003; Tizard, 2014).

The IL-4 cytokine is related to the Th2 pattern that has been most extensively studied (Mena et al., 2002; Kidd, 2003; Tizard, 2014). We did not detect IL-4 in this study; thus, our results were similar to those of previous studies (Ingale et al., 2008; Holmgren et al., 2014), which investigated cytokines in the leukocytes and bronchoalveolar cells of healthy cattle. Eosinophils are the main producers of IL-4 (Voehringer et al., 2004), and they are present in small amounts in the respiratory 
tract of healthy calves (Ackermann et al., 2010). It is believed that under normal conditions, the expression and secretion of this cytokine are minimal, and it is therefore undetectable.

Our results agree with previous studies that reported a predominance of the Th1 response between the first and fifth month of life (Mena et al., 2002; Ohtsuka et al., 2002; Grell et al., 2005b), as we observed via increased expression of IL-12 and TNF- $\alpha$ and low expression of IL-10 at $150 \mathrm{~d}$ (T5). This situation was reversed at T6 (165 d of life).

A previous study (Grell et al., 2005a) showed a predominance of the Th1 response in calves challenged with BRSV at an average age of $120 \mathrm{~d}$, as verified by an increase in IFN- $\gamma$, a typical cell response with a predominance of NK cells, and severe pulmonary inflammation observed by increased haptoglobin, IL-6, and clinical manifestations. When these animals were re-inoculated after 3 mo, a small inflammatory response was observed, with discrete increases of the same variables. This less severe reaction was attributed to age differences or failure of the re-inoculation. If we consider that these findings were due to the influence of age, they are in agreement with the results of our study that examined the change in the profile of cytokines secreted between T5 and T7 (150 and $180 \mathrm{~d}$ of life).

When the dynamics of the bronchoalveolar region were analyzed, it was observed that until T5 (150 d of life), the animals showed a balanced secretory profile between the levels of IgG1 and $\mathrm{IgG} 2$, a low number of macrophages expressing CD14, and increased oxidative metabolism, thus demonstrating a pattern of predominant Th1 response. Because calves between 3 and 5 mo of age produced a greater inflammatory response than younger animals after challenge with pathogens introduced intratracheally, with more intense tissue damage than that found in younger animals (Grell et al., 2005a), it appears that at T5 (150 d of life) calves experience an exaggerated inflammatory response that keeps the respiratory tract healthy.

In further support of this hypothesis, we noted that at T6 (165 d of life), there was a tendency for an increase in IL-10, the regulatory cytokine responsible for suppressing the local inflammatory response (Chaouat et al., 2002). This event coincided with the increased secretion of $\operatorname{IgG1}$ and the reduced production of ROS. This profile is compatible with a regulatory or Th2 response (Kidd, 2003; Tizard, 2014). This finding was similar to that of Souza et al. (2008), who established that an increased secretion of inflammatory cytokines (TNF- $\alpha$ and IL-12), followed by a high response of IL-10, is an attempt to prevent deleterious immune response in the host.

At T7 (180 d of life), the IL-10 mRNA remained constant, and there was a slight increase in IL-12, TNF- $\alpha$, oxidative metabolism, and IgG1 and $\mathrm{IgG} 2$ balance, suggesting that the oscillations that occurred between $\mathrm{T} 5$ and $\mathrm{T} 6$ were related to fine-tuning of the immune response that became effective after $180 \mathrm{~d}$ of age.

Although there were no statistical differences in the functions of CD14+ cells between T1 and T7, it is believed that alveolar macrophages undergo fine-tuning between the third and sixth months of life in healthy calves. It was possible to identify that bronchoalveolar immune defense undergoes gradual maturation up to 6 mo of age in calves. After T4 (135 d of life), the activities of phagocytosis and oxidative metabolism are more efficient than at earlier ages, indicating the possibility that the animals are less susceptible to bronchopneumonia after this age.

Despite the apparently lower susceptibility to bronchopneumonia, it is speculated that when animals are infected at T4 and particularly T5 (135-150 $\mathrm{d}$ of life), they have a higher capacity to produce ROS in ex vivo challenge than at earlier ages. In addition, the predominant response is cellular and not humoral, which can lead to host tissue damage during infection. Regulatory mechanisms begin to become more efficient in T6 and T7 (165-180 d of life), which leads to a cellular response adjustment that is likely caused by a balancing of the cellular and humoral responses.

Further studies are needed to elucidate the response of other, CD14 negative bronchoalveolar cells, and of humoral responses related to the maturation of lymphocytes, particularly B lymphocytes, to determine if, in fact, the efficiency response observed here occurs between T6 and T7. To our knowledge, this is the first study that quantified the bronchoalveolar immune response during the period of establishment of immunity in calves, independent of maternal factors, and under conventional conditions. These findings will support the development of therapies and prophylactic measures for bronchopneumonia that may help to reduce mortality during this period.

We conclude that the immune response has unique characteristics during the establishment of a calf's active immunity, regardless of maternal factors. The alveolar macrophages CD14 undergo fine-tuning between the third and sixth months of life in healthy calves, and do not differ in function between $\mathrm{T} 1$ and T7. They are modulated by 
cytokines of the Th1 profile, which promote a progressive increase in the cytotoxic response until it becomes more reactive, up to maximum at $150 \mathrm{~d}$ of life. Later, cytokines promote fine-tuning that shifts the Th1 profile into a Th2 profile and, after that, achieves a Th1 and Th2 profile balance at day 180 of life.

\section{SUPPLEMENTARY DATA}

\section{Supplementary data are available at Journal of Animal Science online.}

\section{LITERATURE CITED}

Ackermann, M. R., R. Derscheid, and J. A. Roth. 2010. Innate immunology of bovine respiratory disease. Vet. Clin. North Am. Food Anim. Pract. 26:215-228. doi:10.1016/j. cvfa.2010.03.001

Antonis, A. F. G., M. C. Jong, W. H. Van Der Poel, N. Stockhofe-Zurwieden, T. Kimman, and R. S. Schrijver. 2010. Age-dependent differences in the pathogenesis of bovine respiratory syncytial virus infections related to the development of natural immunocompetence. J. Gen. Virol. 91:2497-2506. doi:10.1099/vir.0.020842-0

Batista, C. F., M. G. Blagitz, B. P. Santos, H. G. Bertagnon, A. C. Parra, R. S. Vianna, G. G. de Lucca, D. M. Lima, D. S. Santos, and A. M. Della Libera. 2012. Maturation of mononuclear phagocytes in the lungs of young calves-in vitro study. j. Dairy Sci. 95:5909-5915. doi:10.3168/jds.2012-5321

Bertagnon, H. G., G. V. Z. Esper, M. P. Emanuelli, and L. G. Pellegrine. 2011. Influencia meteorologica no leucograma e na populacao citologica do trato respiratorio de bezerros. Pesq. Vet. Bras. 31:244-246. doi:10.1590/ S0100-736X2011000300010380

Chaouat, G., S. Zourbas, S. Ostojic, G. Lappree-Delage, S. Dubanchet, N. Ledee, and J. Martal. 2002. A brief review of recent data on some cytokine expressions at the materno-foetal interface which might challenge the classical th1/ th2 dichotomy. j. Reprod. Immunol. 53:241-256.

Chase, C. C. L., D. J. Hurley, and A. J. Reber. 2008. Neonatal immune development in the calf and its impact on vaccine response. Vet. Clin. North Am. Food Anim. Pract. 24:87-104. doi:10.1016/j.cvfa.2007.11.001

Cortese, S. V. 2009. Neonatal immunology. Vet. Clin. North Am. Food. Anim. 25:221-227. doi:10.1016/j.cvfa.2008.10.003

Gonçalves, R. C., J. A. N. Lisboa, M. V. Sousa, C. T. Almeida, M. R. G. Kuchembuck, and S. B. Chiacchio. 2000. Aspectos clinicos e epidemiologicos da broncopneumonia dos bezerros em Botucatu, SP. Rev. Bras. Cien. Vet. 7:144-147. doi:10.43221/rbcv2015.200

Gorden, P. J., and P. Plummer. 2010. Control, management, and prevention of bovine respiratory disease in dairy calves and cows. Vet. Clin. North Am. Food Anim. Pract. 26:243-259. doi:10.1016/j.cvfa.2010.03.004

Grell, S. N., U. Riber, K. Tjornehoj, L. E. Larsen, and P. M. H. Heegaard. 2005a. Marked induction of IL-6, haptoglobin and IFNg following experimental BRSV infection in young calves. Vet. Immunol. Immunopathol. 10:235-245. doi:10.1016/j.vetimm.2004.09.02

Grell, S. N., U. Riber, K. Tjornehoj, L. E. Larsen, and P. M. H. Heegaard. 2005b. Age dependent differences in cytokine and antibody responses after experimental RSV infection in a bovine model. Vaccine 2:3412-3423. doi:10.1016/j.vaccine.2005.01.094

Hodge, S. J., G. L. Hodge, M. Holmes, and P. N. Reynolds. 2004. Flow cytometric characterization of cell populations in bronchoalveolar lavage and bronchial brushings from patients with chronic obstructive pulmonary disease. Cytometry B. Clin. Cytom. 61:27-34. doi:10.1002/ cyto.b. 20020

Holmgren, S., M. Hagberg Gustavsson, A. Lundén, and E. Wattrang. 2014. Cytokine mRNA expression in bronchoalveolar lavage cells during Dictyocaulus viviparus infection in calves. Parasite Immunol. 36:78-86. doi:10.1111/pim.12083

Ingale, S. L., P. Singh, O. K. Raina, U. R. Mehra, A. K. Verma, S. C. Gupta, and S. V. Mulik. 2008. Interferon-gamma and interleukin-4 expression during Fasciola gigantica primary infection in crossbred bovine calves as determined by real -time PCR. Vet. Parasitol. 152:158-161. doi:10.1016/j. vetpar.2007.11.023

Kabara, E., L. M. Sordillo, S. Holcombe, and G. A. Contreras. 2014. Adiponectin links adipose tissue function and monocyte inflammatory responses during bovine metabolic stress. Comp. Immunol. Microbiol. Infect. Dis. 37:49-58. doi:10.1016/j.cimid.2013.10.007

Kalina, W. V., A. R. Woolums, and L. J. Gershwin. 2005. Formalin-inactivated bovine RSV vaccine influences antibody levels in bronchoalveolar lavage fluid and disease outcome in experimentally infected calves. Vaccine 23:4625-4630. doi:10.1016/j.vaccine.2005.04.032

Kampen, A. H., T. Tollersrud, S. Larsen, J. A. Roth, D. E. Frank, and A. Lund. 2004. Repeatability of flow cytometric and classical measurement of phagocytosis and respiratory burst in bovine polymorphonuclear leukocytes. Vet. Immunol. Immunopathol. 97:105-114.

Kampen, A. H., I. Olsen, T. Tollersrud, A. K. Storset, and A. Lund. 2006. Lymphocyte subpopulations and neutrophil function in calves during the first 6 months of life. Vet. Immunol. Immunopathol. 113:53-63. doi:10.1016/j. vetimm.2006.04.001

Kidd, P. 2003. Th1/th2 balance: the hypothesis, its limitations, and implications for health and disease. Altern. Med. Rev. 8:223-246.

Koess, C., and J. Hamann. 2008. Detection of mastitis in the bovine mammary gland by flow cytometry at early stages. j. Dairy Res. 75:225-232. doi:10.1017/S0022029908003245

Machugh, D. E., M. Taraktsoglou, K. E. Killick, N. C. Nalpas, J. A. Browne, S. DE Park, K. Hokamp, E. Gormley, and D. A. Magee. 2012. Pan-genomic analysis of bovine monocyte-derived macrophage gene expression in response to in vitro infection with Mycobacterium avium subspecies paratuberculosis. Vet. Res. 43:25. doi:10.1186/1297-9716-43-25

Mena, A., X. P. Ioannou, A. Van Kessel, S. Van Drunen Little-Van Den Hurk, Y. Popowych, L. A. Babiuk, and D. L. Godson. 2002. Th1/th2 biasing effects of vaccination in cattle as determined by real-time PCR. J. Immunol. Methods 263:11-21.

Meyer, G., M. Deplanche, and F. Schelcher. 2008. Human and bovine respiratory syncytial virus vaccine research and development. Comp. Immunol. Microbiol. Infect. Dis. 31:191-225. doi:10.1016/j.cimid.2007.07.008

Ohtsuka, H., H. Kobayashi, M. Kinouch, and Y. Maeda. 2002. Comparison of cytokine mRNA expression in 
peripheral CD4, CD8, $\gamma \delta$ T cells between healthy Holstein and Japanese Black calves. J. Anim. Sci. 85:575-580. doi:10.1111/asj.12175

Pfaffl, M. W., G. W. Horgan, and L. Dempfle. 2002. Relative expression software tool (REST) for group-wise comparison and statistical analysis of relative expression results in real-time pcr. Nucleic Acids Res. 30:e36.

Platt, R., P. W. Widel, L. D. Kesl, and J. A. Roth. 2009. Comparison of humoral and cellular immune responses to a pentavalent modified live virus vaccine in three age groups of calves with maternal antibodies, before and after BVDV type 2 challenge. Vaccine 27:4508-4519. doi:10.1016/j.vaccine.2009.05.012

Prado, M. E., T. M. Prado, M. Payton, and A. W. Confer. 2006. Maternally and naturally acquired antibodies to Mannheimia haemolytica and Pasteurella multocida in beef calves. Vet. Immunol. Immunopathol. 111:301-307. doi:10.1016/j.vetimm.2005.10.013

Reber, A. J., D. C. Donovan, J. Gabbard, K. Galland, M. AcevesAvila, K. A. Holbert, L. Marshall, and D. J. Hurley. 2008. Transfer of maternal colostral leukocytes promotes development of the neonatal immune system PART II. Effects on neonatal lymphocytes. Vet. Immunol. Immunopathol. 123:305-313. doi:10.1016/j.vetimm.2008.02.009

Reinhold, P., G. Becher, and M. Rothe. 2000. Evaluation of the measurement of leukotriene B4 concentrations in exhaled condensate as a noninvasive method for assessing mediators of inflammation in the lungs of calves. Am. J. Vet. Res. 61:742-749.

Soethout, E. C., K. E. Müller, A. J. van den Belt, and V. P. Rutten. 2004. Identification and phenotyping of leukocytes in bovine bronchoalveolar lavage fluid. Clin. Diagn. Lab. Immunol. 11:795-798. doi:10.1128/ CDLI.11.4.795-798.2004

Souza, M., M. S. Azevedo, K. Jung, S. Cheetham, and L. J. Saif. 2008. Pathogenesis and immune responses in gnotobiotic calves after infection with the genogroup II. 4-HS66 strain of human norovirus. J. Virol. 82:1777-1786. doi:10.1128/ JVI.01347-07

Tizard, I. R. 2014. Veterinary immunology: An introduction. 7 th ed. Elsevier, London.

Voehringer, D., K. Shinkai, and R. M. Locksley. 2004. Type 2 immunity reflects orchestrated recruitment of cells committed to Il-4 production. Immunity 20:267-277. 